\title{
Eozinofilų adhezijos poveikis bronchų lygiųjų raumenų proliferacijai sergant astma
}

\author{
EFFECT OF EOSINOPHILS ADHESION TO AIRWAY SMOOTH MUSCLE CELLS \\ PROLIFERATION IN ASTHMA
}

\author{
ANDRIUS JANUŠKEVIČIUSS', IEVA JANULAITYTE் ${ }^{1}$, VIRGINIJA KALINAUSKAITĖ-ŽUKAUSKË², \\ AIRIDAS RIMKŪNAS ${ }^{1}$, BEATRIČE் TAMAŠAUSKAITE் $\dot{H}^{1}$, KĘSTUTIS MALAKAUSKAS ${ }^{1,2}$ \\ ${ }^{1}$ LSMU MA Pulmonologijos klinikos Pulmonologijos laboratorija, ${ }^{2}$ LSMU MA Pulmonologijos klinika
}

\begin{abstract}
Santrauka. I̦vadas. Eozinofilinis kvėpavimo takų uždegimas - svarbus astmos patogenezès komponentas. Eozinofilai yra gebančios adhezuoti ląstelès, nes turi pagrindinius adhezijos receptorius - integrinus, kurie ne tik atlieka prisitvirtinimo funkciją, bet gali elgtis kaip signalo perdavejai abipus komunikuojančių ląstelių. Manoma, kad ne visi eozinofilai pasižymi vienodomis adhezinemis savybėmis ir priklausomai nuo to gali skirtis savo atliekamomis funkcijomis. Taip pat dèl adhezijos per paviršiaus integrinus eozinofilai yra ne tik užlaikomi plaučių audiniuose greta struktūrinių ląstelių, bet gali pakisti ir jų aktyvumas. Geresnis supratimas apie eozinofilų adhezinių savybių svarbą padètų pritaikyti integrinų arba jų ligandų blokavimą specifiniais antikūnais ir taip valdyti poveikị kvejpavimo takų struktūriniams pokyčiams sergantiesiems astma. Tyrimo tikslas - ịvertinti eozinofilų adhezinių savybių svarbą bronchų lygiụjų raumenų (BLR) ląstelių proliferacijai sergantiesiems astma. Tyrimo metodai. I tyrimą ịtraukti septyni naujai diagnozuota astma sergantys pacientai, kurie dar negydyti gliukokortikoidais, ir šeši nerūkantys sveiki asmenys. Eozinofilai iš tiriamųjų periferinio kraujo buvo išskiriami naudojant centrifugavimą aukšto tankio Ficoll gradiente ir magnetinę separaciją. Buvo sudaromos individualiosios kombinuotos kultūros tarp nemirtingos žmogaus BLR ląstelių linijos ir išskirtų eozinofilų, pritaikant ląstelių santykị atitinkamai - 1:6, 1:3 bei 1:1,5 (37 500 BLR ląstelių bei 6250,12500 ir 25000 eozinofilų). Eozinofilų adhezinès savybès ịvertintos matuojant eozinofilų peroksidazės aktyvumą kombinuotose kultūrose. BLR ląsteliu proliferacija vertinta praejus 72 val. po kombinuotos kultūros sudarymo naudojant Alamaro mèlio metodą. Rezultatai. Taikant BLR ląstelių ir sergančiųjų astma eozinofilų santykị kombinuotoje kultūroje 1:6 ir 1:3, buvo gauta panaši prisitvirtinusių

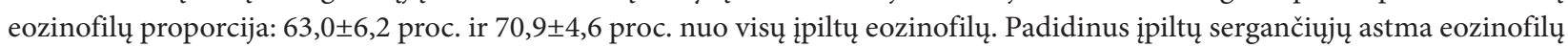

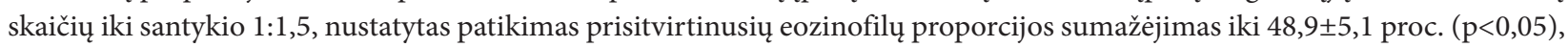
galimai dèl per mažo prisitvirtinimui tinkamų vietų skaičiaus. Tuo tarpu matuojant sveikų asmenų eozinofilų adheziją, rezultatai visais atvejais išliko panašūs, atitinkamai $-45,0 \pm 4,1$ proc., $48,7 \pm 5,7$ proc. ir $49,5 \pm 3,4$ proc. Panaši tendencija pastebèta vertinant ir eozinofilų poveikị BLR ląstelių proliferacijai. Sergančiųjų astma grupejje taikant santykị 1:6 ir 1:3, absoliutusis prisitvirtinusių eozinofilų skaičius kito, tačiau poveikis BLR proliferacijai išliko panašus (atitinkamai 13,0 $\pm 4,1$ proc. ir $14,4 \pm 2,2$ proc. padidejjimas, p<0,05), lyginant su kontrolinių BLR ląstelių proliferacija be eozinofilų poveikio. Tuo tarpu padidinus eozinofilų kiekį iki santykio - 1:1,5, statistiškai patikimo poveikio proliferacijai nenustatyta. Sveikų asmenų grupeje, taikant santyki - 1:6 ir 1:3, patikimos įtakos BLR ląstelių proliferacijai nerasta, tačiau padidinus eozinofilų skaičių iki santykio 1:1,5, nustatytas patikimas $8,5 \pm 3,4$ proc. proliferacijos sumažèjimas $(\mathrm{p}<0,05)$. Išvados. Gebančių adhezuoti eozinofilų santykis periferiniame kraujyje yra pastovus, o eozinofilų aktyvumas bei įtaka BLR ląstelių proliferacijai galimai priklauso nuo jų adhezinių savybių.

Reikšminiai žodžiai: eozinofilai, adhezija, bronchų lygieji raumenys, proliferacija, astma.

Summary. Introduction. Eosinophilic airway inflammation is an important feature in asthma pathogenesis. Eosinophils are adhesive cells, because they have the main adhesion receptors - integrins, that are responsible not only for eosinophils attachment, but also can act as signal-transdusers between communicating cells. It is believed that not all eosinophils are characterized by the same adhesive properties and depending on it can have a different functions. Based on it, better understanding of eosinophils adhesion could be adapted on integrins or their ligands blocking with specific antibodies, reducing eosinophils effect to airway structural changes in asthma. Aim - to evaluate the importance of eosinophils adhesion to airway smooth muscle (ASM) cells proliferation in asthma. Methods. 7 steroids-free asthmatic patients and 6 non-smoking healthy subjects were included into the study. Peripheral blood eosinophils were isolated by using high density Ficoll centrifugation and magnetic seperation. An individual combined cell cultured between immortalised airway smooth muscle (ASM) cells and isolated eosinophils was made, by using different ratio (37,500 and 6,250, 12,500 and 25,000 eosinophils respectively). Eosinophils adhesion was evaluated by measuring eosinophils peroxidase activity in combined cell cultures. ASM cells proliferation after $72 \mathrm{~h}$ of making combined cell cultures by Alamar blue assay. Results. By using the ratio of ASM cells and asthmatic eosinophils 1:6 and 1:3 was received similar attached eosinophils proportion - respectively $63.0 \pm 6.2 \%$ and $70.9 \pm 4.6 \%$ from whole added eosinophils. Increasing
\end{abstract}




\section{Moksliniai darbai ir apžvalgos}

added asthmatic eosinophils count to the ratio 1:1.5 was received significantly reduced proportion of attached eosinophils to $48.9 \pm 5.1(\mathrm{p}<0.05)$, probably due to not enough specific adhesive sites. Meanwhile measuring healthy eosinophils adhesion in all cases results maintain similar, respectively 45.0 $\pm 4.1,48.7 \pm 5.7$ and 49.5 \pm 3.4 . Similar tendency noticed measuring eosinophils effect to ASM proliferation. Although in asthmatic patients group after using ratios 1:6 and 1:3 absolute number of attached eosinophils was different, their effect to ASM cells remains the same (respectively increase in $13.0 \pm 4.1$ and $14.4 \pm 2.2 \%, \mathrm{p}<0.05$ ) comparing with proliferation of control ASM cells, without incubation with eosinophils. Whereas after increasing added asthmatic eosinophils count to the ratio 1:1.5 statistically significant effect to cells proliferation was not received. In healthy eosinophils group after using ratios 1:6 and 1:3 significant effect to ASM cells proliferation was not determined, however, after increasing added asthmatic eosinophils count to the ratio 1:1.5 was received significantly reduced ASM cells proliferation by $8.5 \pm 3.4 \%(\mathrm{p}<0.05)$. Conclusion. Adhesive eosinophils ratio in peripheral blood remains stable and eosinophils activity and effect to ASM cells proliferation depends by eosinophils adhesive properties.

Keywords: eosinophils, adhesion, airway smooth muscle, proliferation, asthma.

\section{IVADAS}

Eozinofilija kvèpavimo takuose - vienas iš astmą charakterizuojančių požymių. Pastaraisiais metais daugèja publikacijų, kuriose siekiama geriau suprasti procesus, lemiančius jų skaičiaus plaučiuose padidèjimą bei poveikį audiniams. Eozinofilų infiltracija $\mathfrak{i}$ plaučių audinị yra pagrindinis uždegiminių procesų veiksnys sergant astma. Toks eozinofilų judejimas iš kraujotakos sistemos yra dinaminis, daugiapakopis procesas, kuris apima ląstelių sukibimo bei riedejimo kraujagyslių endotelio paviršiumi procesus, pirminę aktyvaciją bei adheziją, galiausiai transendotelinę ir subendotelinę migraciją [1]. Pirminè eozinofilų funkcija yra kovoti su patogenais, suskaidant juos citotoksiniu katijoninių baltymų pagalba, kurie saugomi viduląstelinèse granulèse. Nors žinoma, kad dèl šių baltymų eozinofilai gali būti toksiški daugeliui audinių [2], jie taip pat yra svarbus uždegiminių citokinų, chemokinų, augimo veiksnių bei fermentų šaltinis [3], kurių kiekybiniai ir kokybiniai pokyčiai gali sutrikdyti kvèpavimo takų homeostazę bei skatinti remodeliacijos vystymąsi. Dèl šių funkcijų pasiskirstymo eozinofilai gali būti skirstomi ị skatinamuosius ardymo procesus arba remodeliacijos vystymąsi.

Eozinofilai yra galinčios adhezuoti ląstelès, nes jų paviršiuje yra ekspresuojami adhezijos receptoriai, kurių pagalba jie prisitvirtina prie užląstelinio užpildo baltymų arba kitos ląstelès paviršiaus bei leidžia eozinofilams atpažinti juos supančią aplinką ir greitai $\mathfrak{i}$ ją reaguoti. Integrinai yra gausiausi eozinofilų paviršiuje ekspresuojami adhezijos receptoriai [4], o nuo jų aktyvacijos priklauso, ar eozinofilai prisitvirtins prie kraujagyslių endotelio, o taip pat ir transmigracija i plaučius. Integrinai - tai specifiniu ląstelès paviršiaus adhezijos receptorių superšeima, kurie prisijungia prie ląstelès paviršiaus adhezijos molekulių, užląstelinio užpildo baltymų arba tirpių ligandų $[5,6]$. Tai transmembraniniai $\alpha \beta$ heterodimerai, kuriuos sudaro mažiausiai $18 \alpha$ ir $8 \beta$ subvienetai, kartu formuojantys 24 skirtingus jų darinius. Prisijungdami užląstelinius ligandus, integrinai perduoda signalą ì ląstelès vidų ir atvirkščiai - jų veikla gali būti reguliuojama iš ląstelès vidaus gautų signalų [5]. Integrinai sudaro tarpmembraninę jungtị tarp užląstelinio ligando (kitos ląstelès arba užpildo baltymų) ir ląstelès citoskeleto aktino mikrofilamentų. Daug skirtingų baltymų citoplazminèje dalyje, tokių kaip talinas, vinkulinas, moezinas ir kiti aktiną prisijungiantys baltymai, tai yra jungtys tarp citoplazminio integrinų domeno ir citoskeleto lemiant kompleksines sąveikas. Užląstelinio ligando prisijungimas sužadina įvairius signalo perdavimo kelius ir valdo ląstelès elgseną, įskaitant adheziją, proliferaciją, išgyvenamumą, apoptozę, formą, poliškumą, migraciją, genų raišką ir diferenciaciją $[5,7,8]$.

Migravę per kraujagyslių endotelị eozinofilai patenka ị kvèpavimo takus greta BLR sluoksnio arba jungiamojo audinio. Plaučių struktūrinès ląstelès, tokios kaip BLR, fibroblastai, epitelio arba endotelio ląstelès, savo paviršiuje ekspresuoja specifines adhezijos molekules: ICAM-1 ir VCAM-1. Šios molekulès gali atstovauti kaip substratai eozinofilų paviršiaus integrinams $\alpha 4 \beta 1$ ir $\alpha \mathrm{M} \beta 2$, nuo kurių priklauso eozinofilų perèjimas i aktyviąją stadiją astmos metu [9]. Periferinio kraujo eozinofilai turi sąlyginai trumpą gyvenimo pusperiodi - nuo 8 iki 18 val., tuo tarpu migravusių i atinkamus organus eozinofilų gyvybingumas prailgèja iki šešių dienų [10]. Gyvybingumo prailgejjimas gali būti grindžiamas egzistuojančia sąveikia tarp eozinofilų ir struktūrinių ląstelių arba užląstelinio užpildo baltymų, kuri būdinga tik migravusiems $\mathfrak{i}$ audinius eozinofilams.

Sergant astma, patikimai padidejja eozinofilų infiltracija ị kvépavimo takus [11]. Tačiau kvẻpavimo takų remodeliacija, kurios vystymąsi skatina eozinofilai, priklauso ne tik nuo jų skaičiaus kvèpavimo takuose, bet ir nuo adhezijos bei gyvybingumo, kurie tiesiogiai susiję su jų užlaikymu plaučių audiniuose prieš išmigruojant $\mathfrak{i}$ bronchų spindị. Šio tyrimo tikslas išsiaiškinti, ar tiesioginis kontaktas tarp eozinofilų ir BLR ląstelių turi ịtakos jų proliferacijai sergant astma, ar tai priklauso nuo gebančių adhezuoti eozinofilu proporcijos bei specifinių sukibimo vietų skaičiaus kombinuotoje kultūroje. 


\section{Moksliniai darbai ir apžvalgos}

\section{METODAI IR MEDŽIAGOS \\ Tiriamujų kontingentas}

Bendrasis tyrimo protokolas patvirtintas Regioninio Biomedicinos tyrimų Etikos komiteto (leidimo Nr. BE-2-13). Visi tiriamieji pasirašė Informuoto asmens sutikimo formą. I tyrimą įtraukti septyni pacientai, kuriems Lietuvos sveikatos mokslų universiteto ligoninès Kauno klinikų Pulmonologijos klinikoje naujai diagnozuota alerginé astma ir dar negydyti gliukokortikoidais, bei šeši sveiki nerūkantys asmenys (kontrolinè grupè). Alerginè astma buvo diagnozuota remiantis klinikiniais simptomais, ligos anamneze, teigiamais odos dūrio mèginiais prieš dažniausiai pasitaikančius įkvepiamus alergenus bei teigiamu bronchų provokaciniu méginiu su metacholinu. Sveiki asmenys nesirgo jokiomis ligomis ir neturèjo alergijos. Išsamesni tiriamųjų demografiniai ir klinikiniai duomenys pateikiami lentelèje.

\section{Kraujo eozinofilų išskyrimas}

Punktuojant periferinę veną, tiriamųjų kraujas buvo surenkamas ị mėgintuvèlius su antikoaguliantu EDTA $(3 \times 8 \mathrm{ml})$ ir nedelsiant naudotas eozinofilų išskyrimui.

Eozinofilų išskyrimui buvo pritaikomi centrifugavimo aukšto tankio gradiente (Ficoll, GE Healthcare, Suomija) bei magnetinès separacijos (Miltenyi Biotec, JAV) metodai. İ keturis $15 \mathrm{ml}$ centrifuginio tipo mègintuvèlius buvo išpilstytas Ficoll gradientas, užpilant kraujo, praskiesto izotoniniu ir netoksišku fosfatinio buferio druskų tirpalu (PBS) (Lonza, Bio Whittaker, Verier, Belgija). Centrifuguota 600 g 30 min. kambario temperatūroje. Po centrifugavimo susidarę viršutiniai vandeningi sluoksniai buvo pašalinti, o apatiniame mègintuvèlio sluoksnyje susikaupe eritrocitai su granuliocitais. Siekiant atskirti granuliocitus nuo eritrocitų, buvo atliekama hipotoninè eritrocitų lizė su distiliuotu vandeniu.

Granuliocitai resuspenduoti su šaltu MACS buferiu (PBS $\mathrm{pH} 7,2 ; 0,5$ proc. jaučio serumo albumino (BSA) ir 2 mM EDTA), žymèti biotinu konjuguotais monokloniniais antikūnais prieš $\mathrm{CD} 2, \mathrm{CD} 14, \mathrm{CD} 16$, CD19, CD56, CD123 ir CD235A (angl. Biotin-Antibody Cocktail) 10 min. kambario temperatūroje bei su magnetine žyme konjuoguotais antikūnais prieš biotiną (angl. Anti-Biotin MicroBeads) 15 min. kambario temperatūroje. Po inkubacijos granuliocitai buvo centrifuguoti bei frakcionuoti magnetinèse kolonèlèse. Eozinofilai atskirti neigiamos selekcijos būdu. Gyvybingumas vertintas naudojant automatini ląstelių skaičiuotuvą ADAM (Witec AB, Vokietija) pagal gamintojų protokolą.

\section{Bronchų lygiujų raumenų ląstelès}

Eksperimentams naudota sveikų stabiliai telomerazès atvirkštinę transkriptazę ekspresuojančių žmogaus
1 lentelè. Klinikiniai ir demografiniai tiriamųjų duomenys

\begin{tabular}{|c|c|c|}
\hline & $\begin{array}{l}\text { Sergantieji } \\
\text { astma }\end{array}$ & $\begin{array}{c}\text { Sveiki } \\
\text { asmenys }\end{array}$ \\
\hline Skaičius & 7 & 6 \\
\hline Lytis (vyrai/moterys) & $4 / 3$ & $6 / 0$ \\
\hline Amžius (metais) & $26 \pm 3$ & $32 \pm 4$ \\
\hline $\mathrm{FEV}_{1}(\mathrm{I})$ & $3,78 \pm 0,34$ & $3,70 \pm 0,12$ \\
\hline $\begin{array}{l}\text { FEV }_{1} \text { (proc. būtinojo } \\
\text { dydžio) }\end{array}$ & $88,86 \pm 3,36^{*}$ & $114,20 \pm 5,56$ \\
\hline $\mathrm{PD}_{20}(\mu \mathrm{g})$ & $0,12 \pm 0,03$ & - \\
\hline $\begin{array}{l}\text { Kraujo eozinofilų } \\
\text { skaičius, } \times 10^{9} / I\end{array}$ & $0,36 \pm 0,08^{*}$ & $0,2 \pm 0,05$ \\
\hline FeNO, ppb & $60,73 \pm 11,48^{*}$ & $11,53 \pm 2,11$ \\
\hline $\lg E_{,} I U / m l$ & $147,70 \pm 19,50^{*}$ & $23,17 \pm 9,32$ \\
\hline
\end{tabular}

Duomenys pateikiami apskaičiavus vidurki \pm standartinès paklaidos vidurki; ${ }^{*} \mathrm{p}<0,05$, lyginant su sveiku asmenu grupe; $\mathrm{FEV}_{1}$ - iškvepiamo oro tūris per 1 sek.; $\mathrm{PD}_{20}$ - provokacinè metacholino dozè, sukelianti 20 proc. $\mathrm{FEV}_{1}$ sumažejimą; FeNO - azoto monoksido frakcija iškvepiamame ore; $\lg \mathrm{E}$ - imunoglobulinas $\mathrm{E}$.

BLR ląstelių linija [12]. Visiems eksperimentams naudotos ląstelès, po jų atšildymo persètos ne daugiau nei šešis kartus, siekiant išvengti galimų aktyvumo pokyčių dèl ląstelių senéjimo proceso. Ląstelès augintos $75 \mathrm{~cm}^{2}$ ploto auginimo lèkštelèse (Falcon ${ }^{\circledR}$; Corning) $\mathrm{CO}_{2} 5$ proc. koncentracijos bei $37^{\circ} \mathrm{C}$ temperatūroje, keičiant mitybos terpę kas tris dienas. Eksperimentams ląstelès augintos 24 šulinèlių polkštelèse (CytoOne ${ }^{\circledR}$; StarLab) naudojant Dulbeko modifikuotą Eagle mitybos terpę (DMEM) (GIBCO ${ }^{\circledR}$; Life Technologies, Peislis), papildytą streptomicinu/penicilinu (2 proc. v/v; $\mathrm{GIBCO}^{\circ}$; Life Technologies), amfotericinu B (1 proc. v/v; GIBCO $^{\circledR}$; Life Technologies) ir karščiu inaktyvuotu jaučio serumu (FBS) (10 proc. v/v; GIBCO ${ }^{\circledR}$; Life Technologies). Eksperimentų dieną mitybos terpé pakeista i DMEM be FBS, tačiau su antibiotikų mišiniu bei insulino, transferino, seleno (ITS) reagentu $\left(\mathrm{GIBCO}^{\circledR}\right.$; Life Technologies).

\section{Kombinuotỵ kultūrụ auginimas}

Visiems eksperimentams buvo sudarytos individualios kombinuotos kultūros tarp išskirtų eozinofilų ir BLR ląstelių. Remiantis gamintojų rekomendacijomis bei eksperimentiniu planu, 24 šulinèliu plokštelèse eksperimentų dieną būna užaugę apie 37500 BLR ląste-

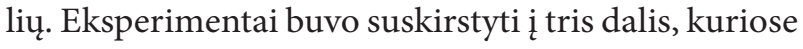
buvo naudojamas skirtingas gyvybingu eozinofilų/ BLR ląstelių santykis - 1:6 (i šulinèlį pridedant 6250 eozinofilų), 1:3 (pridedant 12500 eozinofilų), 1:1,5 (pridedant 25000 eozinofilų). Kombinuotos- kultūros augintos mitybinèje DMEM terpèje be FBS. 


\section{Moksliniai darbai ir apžvalgos}

\section{Eozinofily adhezijos vertinimas}

Eozinofilų adhezija buvo vertinta praejjus 1 val. nuo kombinuotų kultūrų su BLR ląstelèmis sudarymo, pašalinus neprikibusius eozinofilus juos nusiurbiant bei praplaunat šulinèlị su šiltu PBS tirpalu. Eozinofilu adhezija buvo paremta jų viduląstelinès peroksidazès (EPO) aktyvumo matavimais kombinuotose kultūrose [13], naudojant specifinį EPO substratą $\left(1 \mathrm{mM} \mathrm{H}_{2} \mathrm{O}_{2}\right.$, $1 \mathrm{mM} o$-fenilendiaminas, 0,1 proc. Tritonas X-100, ruošiant Tris buferyje; $\mathrm{pH} 8.0$ ). Didesnis prisitvirtinusių eozinofilų skaičius lemia suminį EPO aktyvumo padidejjimą bei intensyvesnę $o$-fenilendiamino oksidacją. Śviesos absorbcija matuota praejus 0,5 val. nuo EPO substrato panaudojimo kombinuotoje kultūroje, reakciją sustabdžius $4 \mathrm{M} \mathrm{H}_{2} \mathrm{SO}_{4}$ tirpalu. Vertinta esant $490 \mathrm{~nm}$ bangos ilgiui naudojant šviesos spektrofotometrą. Rezultatai išreikšti adhezavusių eozinofilų skaičiumi procentais nuo visų i lèkštelę ịpiltų eozinofilų, pritaikant tiesinę kalibracinès kreivès lygtị (visu ipiltų eozinofilų EPO substrato oksidacijos reikšmès).

\section{Proliferacijos vertinimas Alamaro mèlio metodu}

BLR ląstelių proliferacija vertinta praejus 72 val. nuo kombinuotų ląstelių kultūrų su eozinofilais sudarymo. Proliferacija vertinta naudojant Alamaro mèlio reagentą (10 proc. v/v; Invitrogen ${ }^{\mathrm{TM}}$; Life Technologies), praskiestą Hanko balansuotame druskų tirpale $\left(\right.$ GIBCO $^{\circledR}$; Life Technologies). Alamaro mèlis gali būti redukuojamas metabolinio ląstelių aktyvumo metu išsiskiriančių redukuojančiu agentų. Redukcijos intensyvumas vertintas matuojant šviesos absorbciją šviesos spektrofotometru esant $570 \mathrm{~nm}$ ir $600 \mathrm{~nm}$ bangos ilgiui. Rezultatai pateikti BLR ląstelių skaičiaus padidejimu (proliferacija) kombinuotoje kultūroje, remiantis Alamaro mèlio virsmo iš oksiduotos formos ị redukuotą intensyvumu. Kontrolè BLR ląstelès be sąveikos su eozinofilais.

\section{REZULTATAI}

\section{Tiriamujų demografiniai ir klinikiniai duomenys}

I tyrimą buvo ịtraukta 13 tiriamųjų - septyni sergantieji naujai diagnozuota alergine astma bei 6 sveiki nerūkantys asmenys. Sveikų asmenų grupę sudare tik moterys, tačiau literatūrinių duomenų apie nuo lyties priklausomus eozinofilų aktyvumo pokyčius nèra. Sergančiųjų astma grupeje buvo nustatyta patikimai mažesnè $\mathrm{FEV}_{1}$ reikšmé $-114,2 \pm 5,6$ proc. būtinojo dydžio sveikų asmenų grupeje ir $88,9 \pm 3,4$ proc. būtinojo dydžio sergančiųjų astma grupëje. Nustatytas atitinkamai didesnis kraujo eozinofilų skaičius $\left(0,36 \pm 0,08 \times 10^{9} / 1\right.$, lyginant su $\left.0,2 \pm 0,05 \times 10^{9} / 1\right)$, FeNO koncentracija $(60,73 \pm 11,48 \mathrm{ppb}$, lyginant su $11,53 \pm 2,11 \mathrm{ppb})$ ir IgE koncentracija $(147,70 \pm 19,50 \mathrm{IU} / \mathrm{ml}$, lyginant su $23,17 \pm 9,32 \mathrm{IU} / \mathrm{ml}$ ) (1 lentelè).

\section{Eozinofily adhezijos vertinimas}

Eksperimentai buvo atliekami taikant skirtingąBLR ląstelių ir eozinofilų santykị kombinuotoje kultūroje, atitinkamai - 1:6, 1:3 ir 1:1,5 kaip nurodyta metodineje dalyje. Naudojant santykị kombinuotoje kultūroje 1:6 ir 1:3, gautas panašus prisitvirtinusių eozinofilų skaičius, atitinkamai $-63,0 \pm 6,2$ proc. ir $70,9 \pm 4,6$ proc. nuo visų ipiltų eozinofilų. Padidinus sergančiųjų astma eozinofilų skaičių iki santykio 1:1,5 nustatytas patikimas prisitvirtinusių eozinofilų skaičiaus sumažèjimas iki $48,9 \pm 5,1$ proc. $(\mathrm{p}<0,05)$. Tuo tarpu matuojant sveikų asmenų eozinofilų adheziją, rezultatai visais atvejais išliko panašǔs, atitinkamai $-45,0 \pm 4,1$ proc., $48,7 \pm 5,7$ proc. ir $49,5 \pm 3,4$ proc. ( $>0,05$ ) ( 1 pav.).

\section{Eozinofily ịtakos bronchų lygiujų raumeny ląstelių proliferacijai vertinimas}

Sergančiųjų astma grupeje, naudojant santykị 1:6 ir 1:3, proliferacija padidejo atitinkamai $-13,0 \pm 4,1$ proc.

\section{Statistinès analizès metodai}

Statistinè analizè atlikta naudojant GraphPad Prism 6, skirtą Windows operacinei sistemai (versija 6.05, 2014, programinè priemonè Graphpad, Sandiegas, JAV). Duomenys pateikti apskaičiavus vidurkị \pm stardatinès paklaidos vidurkị. Duomenys tarp astmos ir sveikų asmenų grupių laikyti tarpusavyje nesusijusiais, kuriems vertinti taikytas Mann-Whitney U-testas. Duomenys, gauti naudojant to paties tiriamojo asmens periferinio kraujo eozinofilus, bet skirtingu santykiu su BLR ląstelemis, laikyti tarpusavyje susijusiais, kurių vertinimui naudotas Vilkoksono suderintos poros testas. Duomenys statistiškai patikimi, kurių p reikšmé buvo mažesnè kaip 0,05.

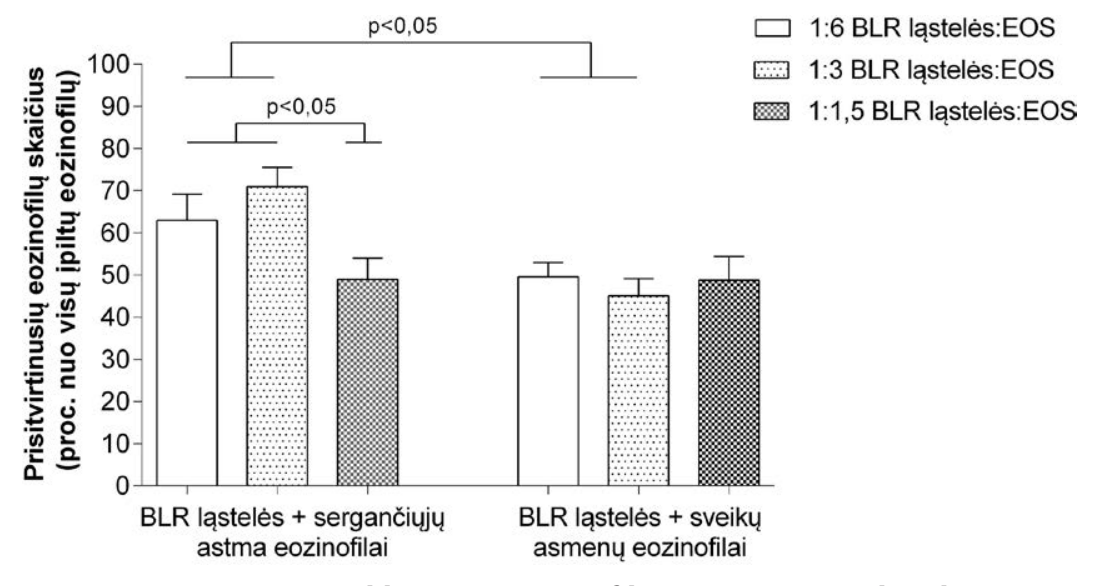

1 pav. Nuo integrinų priklausomo eozinofilų prisitvirtinimo kombinuotoje kultūroje intensyvumas naudojant skirtingą ląstelių santykị

Rezultatai pateikiami apskaičiavus vidurkị \pm standartinės paklaidos vidurkị. Sergančiuju naujai diagnozuota alergine astma $n=7$, sveiku asmenų $n=6$. Rezultatai vertinti praejus 1 val. nuo kombinuotos kultūros augimo pradžios. BLR - bronchų lygieji raumenys. Statistinis patikimumas $p<0,05$. EOS - eozinofilai. 


\section{Moksliniai darbai ir apžvalgos}

ir $14,4 \pm 2,2$ proc. $(\mathrm{p}<0,05)$, lyginant su BLR ląstelių proliferacija be eozinofilų poveikio. Tuo tarpu padidinus eozinofilų kiekį iki santykio 1:1,5, statistiškai patikimo poveikio nenustatyta. Sveikų asmenų grupèje, naudojant santyki 1:6 ir 1:3, patikimos ittakos BLR ląstelių proliferacijai nenustatyta, tačiau, padidinus eozinofilu skaičių iki santykio 1:1,5, nustatytas patikimas $8,5 \pm 3,4$ proc. proliferacijos sumažejimas $(\mathrm{p}<0,05)$ (2 pav.).

\section{REZULTATU APTARIMAS}

Šio tyrimo tikslas - nustatyti, kokią įtaką BLR remodeliacijai gali turèti pakitusi sergančiųuc astma eozinofilu adhezija bei jų aktyvumas, siejamas su intensyvesne infiltracija ị kvèpavimo takus. Šiam tikslui igyvendinti ištyrème eozinofilų adheziją prie BLR ląstelių, naudojant skirtingus šių dviejų ląstelių tipų santykio modelius, bei ịvertinome BLR ląstelių proliferacijos pokyčius šiose kombinuotose kultūrose, rodančius BLR hiperplaziją kvépavimo takuose sergant astma. Nustatėme, kad gebančių adhezuoti eozinofilų santykis periferiniame kraujyje yra pastovus, o eozinofilų aktyvumas bei įtaka BLR ląstelių proliferacijai galimai priklauso nuo ju adhezinių savybių.

Astmos heterogeniškumas bei fenotipų gausa lemia nuolatinị poreikį gerinti jai skirtų terapinių priemonių veiksmingumą bei atrasti naujus, labiau specifiškus gydymo būdus. Vis dažniau gydymas nukreipiamas ị ligos simptomų atsiradimo priežastis, viena jų - vyraujantis eozinofilinis kvėpavimo takų uždegimas. Siekiant suprasti jų itaką kvejpavimo takų remodeliacijos vystymuisi, naudotas unikalus kombinuotų kultūrų modelis tarp sergančiųjų astma periferinio kraujo eozinofilų bei sveikų BLR ląstelių, kuomet galime stebèti tiesioginès sąveikos įtaką abiejų ląstelių fiziologinio aktyvumo pokyčiams. Pirmą kartą tokio tipo eksperimentus atliko Hughes su komanda [14], įrodydami, kad eozinofilai gali prisitvirti prie BLR ląstelių adhezijos molekulių ICAM-1 ir VCAM-1, tačiau išsamesni tyrimai nebuvo atlikti. Šio tyrimo metu siekème išsiaiškinti ne tik tai, kaip pakinta eozinofilų ir BLR ląstelių aktyvumas po tiesioginès jų sąveikos, tačiau ịvertinti ir laisvu adhezijai tinkamų vietų skaičiaus ịtaką bei gebančių adhezuoti kraujo eozinofilų santykį.

Eozinofilai gali veikti dvejopai: būti ardančiosios efektorinès ląstelès ir ardyti kitas struktūras per išskiriamus citotoksinius katijoninius baltymus, arba dalyvauti uždegiminiuose procesuose, išskiriant remodeliacijos vystymąsi skatinamuosius mediatorius $[15,16]$. Pastaroji jų funkcija laikoma svarbiausia astmos patogenezei. Žinoma, kad astmos metu eozinofilų aktyvumas kinta [17] ir didesnè jų dalis migruoja iš kraujo i sergančiųjų astma kvépavimo takus [18]. Tam, kad eozinofilai galètų prisitvirtinti prie kraujagyslių endotelio bei migruoti ị plaučių audinius, dalis jų paviršiaus integrinų turi būti dalinai arba pilnai aktyvioje konformacijoje, tam, kad atsilaisvintų aktyvusis integrinų centras. Atliktais eksperimentais įrodyta, kad sergančiųjų astma eozinofilų adhezija yra intensyvesnè, lyginant su sveikų asmenų eozinofilais (1 pav.) [19]. Nors tai susiję ir su intensyvesne jų paviršiaus integrinų ekspresija [20], tačiau tikètina, kad dèl chemoatraktantų, tokių kaip eotaksinas, veikimo daugiau paviršiaus integrinų yra aktyviojoje konformacijoje. Integrinai yra sudaryti ir dviejų grandinių $\alpha$ ir $\beta$, kurių suartejjimas ir susijungimas plazminejje eozinofilų membranoje lemia dimerų susidarymą, o galiausiai specifinių vietų atsipalaidavimą, prie kurių gali jungtis ligandai. Ligandus gali atstoti užląstelinio užpildo baltymų, pagrinde fibronektino, specifiniai Arg-Gly-Asp (RGD) aminorūgščių motyvai, arba ląstelių ICAM-1 ir VCAM-1 adhezijos molekulès [21]. Tiek mūsų naudotoje kombinuotoje kultūroje in vitro, tiek plaučių audiniuose in vivo, struktūrinès ląstelès, pvz., BLR ląstelès arba plaučių fibroblastai, pasižymi minètų adhezijos molekulių ekspresija bei patys išskiria užląstelinio užpildo baltymus, užtikrinant visas sąlygas eozinofilų adhezijai. Vertindami adheziją in vitro modelyje, pastebejjome iki šiol mokslininkų neaptartą tendenciją, kad išlaikant pastovias sąlygas, eozinofilų adhezija priklauso nuo jų ịpilamo kiekio ị kombinuotą kultūrą. Tai reiškia, kad, nesant pakankamam laisvų adhezijos vietų skaičiaus, aktyvintas eozinofilas negalètų prisitvirtinti plaučių audinyje. Tai rodo naują galimą tyrimų kryptị, vertinant plaučių struktūrinių 


\section{Moksliniai darbai ir apžvalgos}

ląsteliu adhezijos molekulių ekspresijos pokyčius bei užląstelinio užpildo baltymų remodeliaciją sergant astma, nes nustatytas padidejęs eozinofilų kiekis plaučių audiniuose signalizuoja ir galimus pokyčius šiose srityse.

Manome, kad tam, jog sergant astma eozinofilai veiktų arba ardančiai, arba skatintų remodeliacijos vystymąsi, reikia tiek kokybinių, tiek kiekybiniu eozinofilų pokyčių kvejpavimo takuose. Jeigu suvaldyti eozinofilų aktyvumo pokyčius, sergant astma, yra itin sudètinga, gali padèti kombinuotas gydymas su siekiu sumažinti jų skaičių kvejpavimo takuose. Vertinant gautus tyrimo duomenis, nustatyta, kad eozinofilai skatina BLR ląstelių proliferaciją iki tam tikro lygio, kada padidejęs eozinofilų kiekis neturi teigiamos ittakos jų proliferacijai. Galima daryti išvadą, kad eozinofilų skatinamą remodeliacijos procesą užgožia didejjantis ardančiųjų eozinofilų santykis (2 pav.). Nors santykio nepakanka, kad poveikis proliferacijai taptų neigiamas, galima daryti išvadą, kad tiek adhezavę, tiek cirkuliuojantys eozinofilai yra pakankamai aktyvuoti dar kraujyje, todèl netgi neprisitvirtinę eozinofilai yra pakankamai aktyvūs. İdomesni rezultatai sveikų asmenų grupeje, kur nustatyta, kad eozinofilu adhezija nepriklauso nuo santykio su BLR ląstelèmis, nes tik apie pusès eozinofilų integrinai buvo pakankamai aktyvioje konformacijoje, kad galètų adhezuoti. Tai dalinai rodo jų ịtaką BLR ląstelių proliferacijai, kur pastebima, kad aktyvių remodeliaciją skatinančių eozinofilų kiekio, naudojant santykị 1:6 bei 1:3, nepakanka, kad būtų pasiektas patikimas BLR ląsteliụ proliferacijos padidejimas. Tuo tarpu nustatytas proliferacijos sumažejimas, padidinus eozinofilų kiekị iki santykio 1:1,5, rodo, kad didžioji dalis eozinofilų normaliomis sąlygomis atlieka ardomąą funkciją ir nèra atsvaros neutralizuojant jų poveikị remodeliaciją skatinamaisiais eozinofilais. Tai iš dalies patvirtina teoriją, kad dèl vyraujančio lètinio uždegimo, sergant astma pakinta eozinofilu aktyvacija ir adhezinès savybès bei santykis tarp remodeliacija arba ardymo procesus skatinamųjų kraujo eozinofilų.

\section{IŠVADOS}

Nustatėme, kad egzistuoja pastovus adhezuoti gebančių eozinofilų kiekis periferiniame kraujyje, kuris pakinta sergant astma, taip pat pastebejome, kad, esant astmai, eozinofilu adhezija pakinta ir tai turi įtakos jų poveikiui BLR ląstelių proliferacijai. Taip pat sergančiųjų astma eozinofilai galimai labiau pasižymi remodeliaciją skatinamosiomis savybèmis, lyginant su sveikų asmenų eozinofilais, kurie labiau skatina ardančiuosius procesus, išskirdami citotoksinius baltymus.

Gauta 20190301

Priimta 20190403

\section{LITERATŪRA}

1. Konya V, Peinhaupt M, Heinemann A. Adhesion of eosinophils to endothelial cells or substrates under flow conditions. Methods Mol Biol. 2014; 1178:143-56.

2. Rothenberg ME, Hogan SP. The eosinophil. Annu Rev Immunol. 2006; 24:147-74.

3. McBrien CN, Menzies-Gow A. The biology of eosinophils and their role in asthma. Front Med (Lausanne). 2017; 4:93.

4. Johansson MW, Kelly EA, Busse WW, Jarjour NN, Mosher DF. Up-regulation and activation of eosinophil integrins in blood and airway after segmental lung antigen challenge. J Immunol. 2008; 180(11):7622-35.

5. Luo B-H, Carman CV, Springer TA. Structural basis of integrin regulation and signaling. Annu Rev Immunol. 2007; 25:619-47.

6. Hynes RO. Integrins: bidirectional, allosteric signaling machines. Cell. 2002; 110(6):673-87.

7. Streuli CH. Integrins and cell-fate determination. J Cell Sci. 2009; 122(2):171-7.

8. Huttenlocher A, Horwitz AR. Integrins in cell migration. Cold Spring Harbor Perspect Biol. 2011; 3(9):a005074.

9. Johansson MW. Eosinophil activation status in separate compartments and association with asthma. Front Med (Lausanne). 2017; 4:75.

10. Marichal T, Mesnil C, Bureau F. Homeostatic eosinophils: characteristics and functions. Front Med (Lausanne). 2017; $4: 101$.

11. George L, Brightling CE. Eosinophilic airway inflammation: role in asthma and chronic obstructive pulmonary disease. Ther Adv Chronic Dis. 2016; 7(1):34-51.

12. Gosens R, Stelmack GL, Dueck G, McNeill KD, Yamasaki A, Gerthoffer WT, et al. Role of caveolin-1 in p42/p44 MAP kinase activation and proliferation of human airway smooth muscle. Am J Physiol Lung Cell Mol Physiol. 2006; 291(3):L523-34.

13. White SR, Kulp GV, Spaethe SM, Van Alstyne E, Leff AR. A kinetic assay for eosinophil peroxidase activity in eosinophils and eosinophil conditioned media. J Immunol Methods. 1991; 144(2):257-63

14. Hughes JM, Arthur CA, Baracho S, Carlin SM, Hawker KM, Johnson PR, et al. Human eosinophil-airway smooth muscle cell interactions. Mediators Inflamm. 2000; 9(2):93-9.

15. Furuta GT, Atkins FD, Lee NA, Lee JJ. Changing roles of eosinophils in health and disease. Ann Allergy Asthma Immunol. 2014; 113(1):3-8.

16. Kita $\mathbf{H}$. Eosinophils: multifaceted biological properties and roles in health and disease. Immunol Rev. 2011;242(1):161-77.

17. Johansson MW. Activation states of blood eosinophils in asthma. Clin Exp Allergy. 2014; 44(4):482-98.

18. Possa SS, Leick EA, Prado CM, Martins MA, Tibério IFLC. Eosinophilic inflammation in allergic asthma. Front Pharmacol. 2013; 4:46

19. Januskevicius A, Vaitkiene S, Gosens R, Janulaityte I, Hoppenot D, Sakalauskas R, et al. Eosinophils enhance WNT-5a and TGF- $\beta 1$ genes expression in airway smooth muscle cells and promote their proliferation by increased extracellular matrix proteins production in asthma. BMC Pulm Med. 2016; 16(1):94.

20. Januskevicius A, Gosens R, Sakalauskas R, Vaitkiene S, Janulaityte I, Halayko AJ, et al. Suppression of eosinophil integrins prevents remodeling of airway smooth muscle in asthma. Front Physiol. 2017; 7:680.

21. Barthel SR, Johansson MW, McNamee DM, Mosher DF. Roles of integrin activation in eosinophil function and the eosinophilic inflammation of asthma. J Leukoc Biol. 2008; 83(1):1-12. 